\title{
MASS TRAPPING FOR JAPANESE BEETLE (COLEOPTERA: SCARABAEIDAE) SUPPRESSION IN ISOLATED AREAS
}

\author{
by Robert P. Wawrzynski' and Mark E. Ascerno ${ }^{2}$
}

\begin{abstract}
Mass trapping to reduce an isolated population of Japanese beetles (Popillia japonica) was investigated. Four years of mass trapping produced a $97 \%$ reduction in $P$. japonica numbers. Although this study lacked strict statistical controls, we feel it shows mass trapping for isolated Japanese beetle populations has merit. Therefore, under certain conditions mass trapping, as part of an integrated pest management program, may be useful for reducing $P$. japonica populations.
\end{abstract}

The Japanese beetle (Popillia japonica) is a pest of turf and ornamentals in the northeastern United States. The adult beetle, which is responsible for defoliation, has a very wide host range, feeding on over 300 species of plants (Fleming 1972). This wide host range allows the beetle to adapt and thrive in many locales. Although a population is well established in all states east of the Mississippi River (except Mississippi and Florida), many states in the central United States are just beginning to detect its presence (Alm et al. 1996).

Trapping adult beetles with a commercially available synthetic sex and floral lure has been used as a monitoring tool and attempted as a control technique (Klein 1981). Single and multiple trap arrangements for controlling Japanese beetles in urban landscapes in the eastern United States have proven ineffective. Traps often attract more beetles to an area than would otherwise be present, thus increasing defoliation (Gordon and Potter 1985, 1986). These studies, however, took place in high-density beetle population areas. Mass trapping of beetles in a given area has shown mixed results as to the effectiveness of eliminating large numbers of beetles in that area (Fleming et al. 1940; Hamilton et al. 1971). However, studies have suggested that mass trapping of Japanese beetles is a possibility (Langford et al. 1940; Cory and Langford 1955; Klein 1981).
In this study, we report on efforts to control an isolated population of Japanese beetles in Minneapolis, Minnesota. A small pocket of Japanese beetles was discovered in a city park along the Mississippi River. The beetles were apparently brought to the area on infested plant materials. Our 4-year study assessed population density, emergence times, and control efficacy for the area.

\section{Materials and Methods}

An area of approximately 15 acres bordering the Mississippi River in Minneapolis, Minnesota, was used for this study. This site contained an isolated population of Japanese beetles. The site consisted of turf and woods, as well as planted beds in parking lots containing various trees and shrubs. Traps used were Trece Catch Can Japanese Beetle Traps (Salinas, California). Tops (baffles) and bottoms (catch cans) were green, and traps were

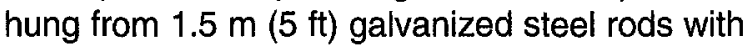
the rim of the funnel approximately $1.2 \mathrm{~m}(4 \mathrm{ft})$ above ground. Traps were baited with The Japanese Beetle Bait, BiolureR System (Consep Membranes, Inc.). Bait consisted of $1.5 \mathrm{mg}(0.017 \%)$ of Japanese beetle sex pheromone [(Japonilure): (R, Z)-5-1-(1-Decenyl) dihydro-2(3H)-furanone], and $4.2 \mathrm{~g}$ of Japanese beetle floral lure $(25.233 \%$ Eugenol, $10.698 \%$ Geraniol, and $10.698 \% 2-$ Phenethyl Propionate)] per lure. Bait packets were attached directly to trap baffles.

Traps were placed at a density of 10 traps per acre during the 1994 season for a total of 150 traps. During the 1995, 1996, and 1997 seasons, 84 traps were placed in the 15-acre site (5.6 traps per acre). This reduction in trap numbers was based on the 1994 trapping season when it was determined that traps with 0 beetle captures would be eliminated. The 84 traps were concentrated in the high-catch areas, as determined by 1994 catch data, for the 
1995, 1996, and 1997 trapping seasons. All lost traps were replaced weekly during the season to maintain a consistent trap density. Traps were monitored daily from 1 June until the first beetle capture(s) and then weekly thereafter until the fall when at least 2 weeks of 0 beetle captures was recorded. All beetles were counted and numbers recorded for each trap at each sampling date. Trapped beetles were removed from the trapping area and destroyed.

A control site was monitored in Hastings, Minnesota (approximately $40 \mathrm{~km}$ [25 mi] southeast of Minneapolis), by the Minnesota Department of Agriculture (MDA) in 1994, 1995, and 1996. Beetle numbers for this site were obtained from the MDA to be used as a comparison to the trapping area in Minneapolis. Beetle captures reported for this site are based on 4 traps (placed in the same location each year) monitored from 1994 to 1996 . Numbers are reported as totals for the entire season for each year.

\section{Results and Discussion}

1994 trapping season. The first beetle trap catch occurred on 21 June; beetles were trapped until 4 October. Trapping was stopped on 18 October after 2 consecutive weeks of no beetle captures. Peak trap catch occurred on 2 August (Figure 1). The trap catch during the 1994 season totaled 4,451 beetles (Table 1). Beetle captures occurred mainly in and around 2 parking areas where a species of wild rose (Rosa rugosa) appeared to attract high numbers of beetles.

Although no evidence of significant plant defoliation was noticed, the Minneapolis Park and Recreation Board made 2 insecticide (acephate) applications on 14 July and 16 August. These applications were targeted to the wild roses in the 2 parking areas only. It appeared that the 14 July application may have slowed the beetles slightly, but they appeared to quickly recover and continue their upward trend. The 16 August application also appeared to only slightly affect the population (Figure 1). The number of beetles recorded at the Hastings control site was 495 (Figure 6, p. 306).

1995 trapping season. The first beetle-trap catch occurred on 6 July, and beetles were trapped until 14 September. Trapping was
Table 1. Japanese beetle captures, 1994.

\begin{tabular}{lclc}
\hline Date & $\begin{array}{l}\text { Beetle } \\
\text { captures }\end{array}$ & Date & $\begin{array}{l}\text { Beetle } \\
\text { captures }\end{array}$ \\
\hline $6 / 21$ & 3 & $8 / 23$ & 297 \\
$6 / 28$ & 31 & $8 / 30$ & 114 \\
$7 / 5$ & 112 & $9 / 6$ & 15 \\
$7 / 12$ & 329 & $9 / 13$ & 36 \\
$7 / 19$ & 329 & $9 / 20$ & 15 \\
$7 / 26$ & 622 & $9 / 27$ & 2 \\
$8 / 2$ & 1,138 & $10 / 4$ & 1 \\
$8 / 9$ & 961 & $10 / 11$ & 0 \\
$8 / 16$ & 456 & $10 / 18$ & 0 \\
& & Total & $\mathbf{4 , 4 5 1}$ \\
\hline
\end{tabular}

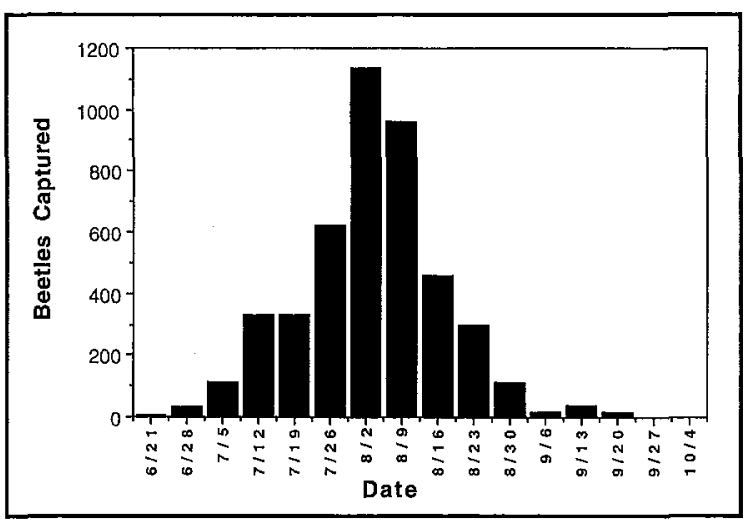

Figure 1. Japanese beetle captures by week, 1994.

stopped on 28 September after 2 consecutive weeks of no beetle captures. Peak trap catch occurred on 17 August (Figure 2). A total of 78 beetles was trapped during the 1995 season (Table 2). Beetle captures occurred mainly in and around the 2 parking areas.

This reduction (98\%) from 1994 levels was somewhat surprising. It is possible that the pesticide applications in 1994 had some effect on the population (i.e., reduced reproduction due to fewer beetles) but, based on a lack of visible impact in 1994, it is doubtful that this is a significant factor. In addition, Ladd et al. (1983) showed that trap placement in insecticide-treated areas did not increase beetle kill and suggested that insecticides actually may repel beetles from treated foliage. Although acephate was not used in those studies, it certainly may help explain why we did not see greater reductions in the populationsagain indicating that the insecticides were probably not a significant factor in the reduction. 
Table 2. Japanese beetle captures, 1995.

\begin{tabular}{lclc}
\hline Date & $\begin{array}{l}\text { Beetle } \\
\text { captures }\end{array}$ & Date & $\begin{array}{l}\text { Beetle } \\
\text { captures }\end{array}$ \\
\hline $7 / 6$ & 1 & $8 / 24$ & 5 \\
$7 / 13$ & 11 & $8 / 31$ & 3 \\
$7 / 20$ & 5 & $9 / 7$ & 0 \\
$7 / 27$ & 9 & $9 / 14$ & 3 \\
$8 / 3$ & 13 & $9 / 21$ & 0 \\
$8 / 10$ & 12 & $9 / 28$ & 0 \\
$8 / 17$ & 16 & Total & 78 \\
\hline
\end{tabular}

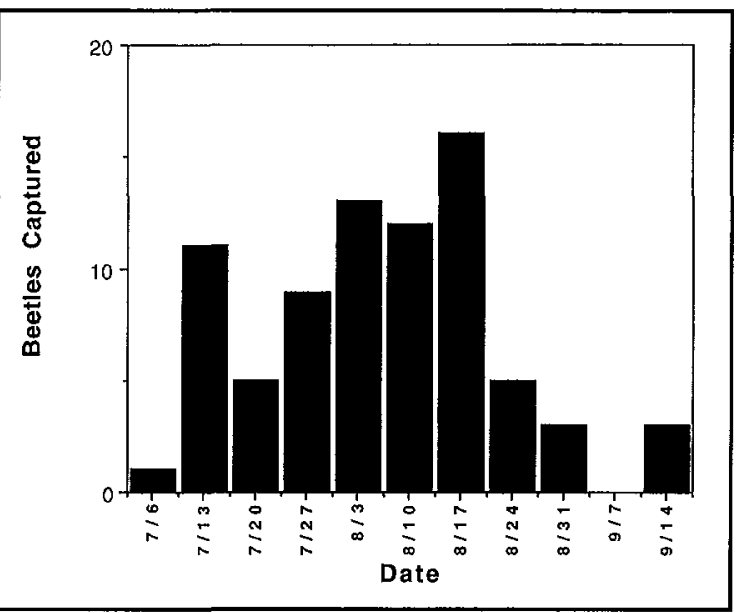

Figure 2. Japanese beetle captures by week, 1995.

The Hastings control site produced 626 beetles during the 1995 season, or a $26 \%$ increase from 1994 (Figure 6, p. 306). Although in a different location, it at least suggests that beetle populations in other areas were not declining.

Another explanation for the $98 \%$ reduction from 1994 was the possibility of a 2-year life cycle for the Japanese beetle in Minnesota. If this were the case, the following year (1996) should have shown significantly increased numbers. Figure 5 (p. 306) indicates this did not happen. Although we could not locate any grubs to determine beetle life history, it is generally thought that the Japanese beetle has a 1-year life cycle in Minnesota as it does elsewhere in the United States.

The reduction in trap numbers during this and the following seasons also should have had little effect on the population reduction. Trap locations that produced no beetles in 1994 were removed and in the following 2 seasons, traps were concentrated in high-catch areas based on the previous season's numbers.
1996 Trapping Season. The first beetle trap catch occurred on 17 July; beetles were trapped until 18 September. Trapping was stopped on 2 October after 2 consecutive weeks of no beetle captures. Peak trap catch occurred on 21 August (Figure 3). A total of 178 beetles was trapped during the 1996 season (Table 3), still a $96 \%$ reduction from 1994. Beetle captures occurred mainly in and around the 2 parking areas. The Hastings control site recorded a total of 510 beetles or an $18 \%$ decrease from 1995 (Figure 6, p. 306).

1997 trapping season. The first beetle trap catch occurred on 28 June, and beetles were trapped until 30 September. Trapping was stopped on 14 October after 2 consecutive weeks of no beetle captures. Peak trap catch occurred on 12 August (Figure 4). A total of 129 beetles was trapped during the 1997 season (Table 4), still a $97 \%$ reduction from 1994 . Beetle captures occurred mainly in and around the 2 parking areas. No report from the Hastings control site was recorded in 1997.

Table 3. Japanese beetle captures, 1996.

\begin{tabular}{lllc} 
Date & $\begin{array}{l}\text { Beetle } \\
\text { captures }\end{array}$ & Date & $\begin{array}{l}\text { Beetle } \\
\text { captures }\end{array}$ \\
\hline $7 / 17$ & 4 & $8 / 28$ & 26 \\
$7 / 24$ & 18 & $9 / 4$ & 13 \\
$7 / 31$ & 13 & $9 / 11$ & 11 \\
$8 / 7$ & 21 & $9 / 18$ & 3 \\
$8 / 14$ & 32 & $9 / 25$ & 0 \\
$8 / 21$ & 37 & $10 / 2$ & 0 \\
& & Total & $\mathbf{1 7 8}$ \\
\hline
\end{tabular}

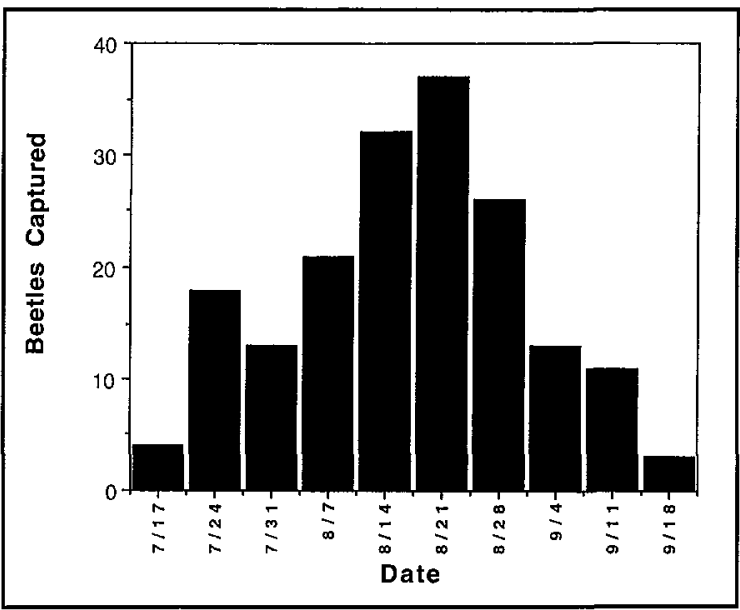

Figure 3. Japanese beetle captures by week, 1996. 


\section{Conclusions}

Upon completing the 1997 trapping season and seeing only small fluctuations in beetle numbers from 1995 to 1997, it appears that the mass trapping played a large role in initially reducing this isolated population. We realize the lack of strict statistical controls limits the scope of this study (although the control site showed fairly consistent trap catches for 1994 to 1996 , indicating no natural, significant population decrease), but we certainly feel that trapping was a significant factor in the population control effort at our study site. It may not be possible to state from this study that trapping alone will reduce Japanese populations in isolated areas. The data do suggest however, that trapping can play an important role in an integrated pest management plan for dealing with Japanese beetles under similar circumstances.

Table 4. Japanese beetle captures, 1997.

\begin{tabular}{llll}
\hline Date & $\begin{array}{l}\text { Beetle } \\
\text { captures }\end{array}$ & Date & $\begin{array}{l}\text { Beetle } \\
\text { captures }\end{array}$ \\
\hline $6 / 28$ & 1 & $8 / 26$ & 25 \\
$7 / 2$ & 0 & $9 / 2$ & 6 \\
$7 / 9$ & 0 & $9 / 9$ & 8 \\
$7 / 15$ & 1 & $9 / 16$ & 4 \\
$7 / 22$ & 2 & $9 / 23$ & 3 \\
$7 / 29$ & 5 & $9 / 30$ & 1 \\
$8 / 5$ & 23 & $10 / 7$ & 0 \\
$8 / 12$ & 36 & $10 / 14$ & 0 \\
$8 / 19$ & 14 & Total & 129 \\
\hline
\end{tabular}

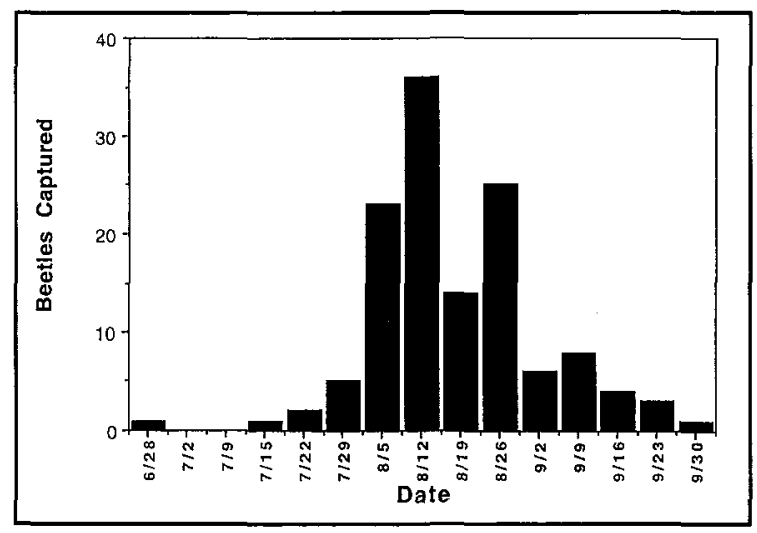

Figure 4. Japanese beetle captures by week, 1997.

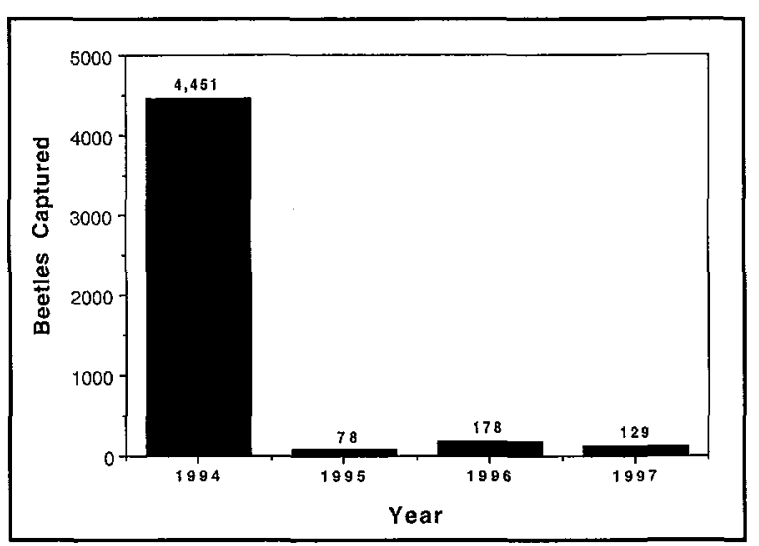

Figure 5. Total beetles captured by year, Minneapolis (test site).

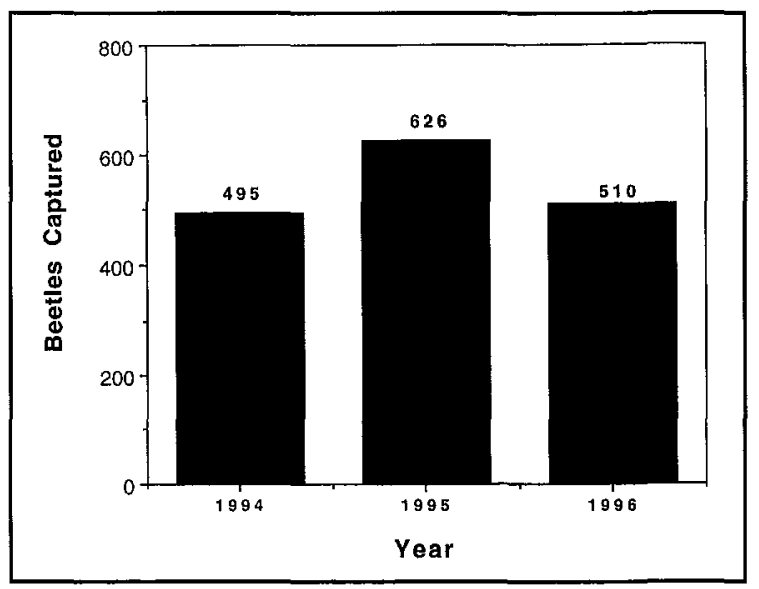

Figure 6. Total beetles captured by year, Hastings (control site).

\section{Literature Cited}

Alm, S.R., I. Yeh, C.G. Dawson, and M.G. Klein. 1996. Evaluation of trapped beetle repellency, trap height, and string pheromone dispensers on Japanese beetle captures (Coleoptera: Scarabaeidae). Environ. Ent. 25(6):1274-1278.

Cory, E.N., and G. S. Langford. 1955. The Japanese Beetle Retardation Program in Maryland. Md. Univ. Ext. Bull. 156. 20 pp.

Fleming, W.E. 1972. Biology of the Japanese Beetle. USDA Tech. Bull. 1449.

Fleming, W.E., E.D. Burgess, and W.W. Maines. 1940. The Use of Traps Against the Japanese Beetle. U.S. Dept. Agric. Circ. 594.

Gordon, F.C., and D.A. Potter. 1985. Efficiency of Japanese beetle (Coleoptera: Scarabaeidae) traps 
in reducing defoliation of plants in the urban landscape and effect on larval density in turf. J. Econ. Ent. 78(4):774-778.

Gordon, F.C., and D.A. Potter. 1986. Japanese beetle (Coleoptera: Scarabaeidae) traps: Evaluation of single and multiple arrangements for reducing defoliation in urban landscapes. J. Econ. Ent. 79(5):1381-1384.

Hamilton, D.W., P.H. Schwartz, B.G. Townsend, and C.W. Jester. 1971. Traps reduce and isolated infestation of Japanese beetle. J. Econ. Ent. 64(1):150-153.

Klein, M.O. 1981. Mass trapping for suppression of Japanese beetles, pp 183-190. In Mitchell, E.R. (Ed.). Management of Insect Pests With Semiochemicals. Plenum Press, New York, NY.

Ladd, T.L., K.O. Lawrence, and M.G. Klein. 1983. Traps and insecticide-treated foliage for use against the Japanese beetle (Coleoptera: Scarabaeidae). J. Econ. Ent. 76(3):551-553.

Langford, G.S., S.L. Crosthwait, and F.B. Whittington. 1940. The value of traps in Japanese beetle control. J. Econ. Ent. 33(2):317-320.

Acknowledgements. The authors would like to acknowledge and thank the Minneapolis Park and Recreation Board for their support of this study; specifically, Ralph Sievert, Ed Rain, Jim Hermann, and Paul Domholt. We would also like to thank Tim Congdon and Ben Johnson for their contributions. Also, we thank the Minnesota Department of Agriculture for their assistance in data collection.

${ }^{1}$ g20 Sun Valley Dr.

Woodland Park, CO 80863

${ }^{2}$ Department of Entomology

University of Minnesota

St. Paul, MN 55108
Résumé. L'utilisation de la capture de masse pour réduire une population isolée de scolytes japonais (Popillia japonica) a été testée. Quatre années de capture de masse ont permis de réduire de $97 \%$ les nombres de $P$. japonica. Même si cette étude n'a pas fait l'objet de contrôles statistiques strictes, nous sommes d'avis que la capture de masse a démontré son mérite pour des populations isolées de scolytes japonais. La capture de masse au sein d'un programme intégré de lutte peut être utile pour diminuer les populations de $P$. japonica sous certaines conditions.

Zusammenfassung. Hier wurde der Einsatz von Massenfallen zur Verminderung einer isolierten Population von Japanischen Käfern (Popillia japonica) untersucht. Eine Fallenstellung über vier Jahre verursachte eine Verminderung der Käferpopulation um $97 \%$. Obwohl es dieser Studie an einer strengen statistischen Kontrolle mangelt, meinen wir, daß die Fallenstellung bei isolierten Japan-Käferpopulationen seine Vorzüge hat. Der Einsatz von Massenfallen als Teil eines Programmes zum Integrierten Pflanzenschutz kann bei der Kontrolle von P. japonica-Populationen unter bestimmten Bedingungen nützlich sein.

Resumen. Fue investigado el uso de trampas para reducir una población aislada de escarabajo japonés (Popillia japonica). Cuatro años de trampeo produjeron un $97 \%$ de reducción en $P$. japonica. Aunque este estudio careció de estrictos controles estadísticos, creemos que las trampas para poblaciones aisladas de escarabajo japonés tienen mérito. Las trampas como parte de un programa de manejo integrado de plagas, pueden ser útiles para reducir poblaciones de $P$. japonica bajo condiciones apropiadas. 